\title{
The Effect of Clove Leaf Methanol Extract on the Profiles of Superoxide Dismutase and Malondialdehyde in the Liver of Rabbits under Hypercholesterolemia Condition
}

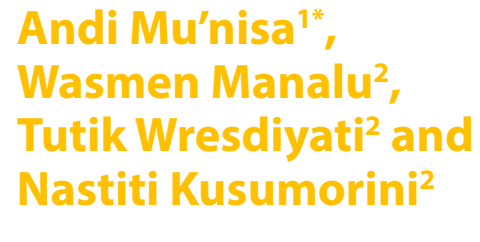

Universitas Negeri Makassar, Indonesia Institut Pertanian Bogor, Indonesia

Corresponding author: Andi Mu'nisa

andi.munisa@unm.ac.id

Jl. Daeng Tata Raya Kampus Parangtambung, FMIPA, Indonesia

Tel: 0411-869834,

Fax: 0411-868794

April 09, 2015; Accepted: April 14 , 2015; Published: April 17, 2015

\begin{abstract}
The study was conducted to observe the effect of clove leaf methanol extract on the profile of superoxide dismutase (SOD) and malondialdehyde (MDA) in the liver of rabbits under hypercholesterolemia. Nine male New Zealand rabbits were used for this study. They were divided into three groups i.e (1) negative control group, (2) Positive control group (hypercholesterolemic) was fed with diet containing 1\% cholesterol for 50 days, and (3) the group was given clove leaf extract and 1\% cholesterol for 50 days. The hypercholesterolemic condition decreased SOD activity and $\mathrm{Cu}, \mathrm{Zn}$-SOD level, otherwise the increasing of MDA level occurred on the liver of the rabbits in the positive control group compared to negative control group. On the other hand, the third group showed the increase of SOD activity and $\mathrm{Cu}, \mathrm{Zn}-\mathrm{SOD}$ level with clove leaf methanol extract. The best results were obtained in the rabbits treated with clove methanol extract simultaneously for 50 days.
\end{abstract}

Clove leaf methanol extract; Rabbit liver; Superoxide dismutase; Malondialdehyde

\section{Introduction}

Reactive oxygen species (ROS), sometimes called active oxygen species, are various forms of activated oxygen, which include free radicals such as superoxide ions $\left(\mathrm{O}_{2}^{-}\right)$and hydroxyl radicals $\left({ }^{\circ} \mathrm{OH}\right)$, as well as non free-radikal species such as hydrogen peroxide $\left(\mathrm{H}_{2} \mathrm{O}_{2}\right)$. In living organisms, various RoSs can form in different ways, including normal aerobic respiration, stimulated polymorphonuclear leukocytes and macrophages, and peroxisomes. These appear to be the main endogenous sources of the most oxidants which are produced by cell. Exogenous sources of free radicals include tobacco smoke ionizing radiation, certain pollutants, organic solvents, and pesticides. Free radicals can cause lipid peroxidation in food, which leads to their deterioration. When produced in excess, ROSs can cause tissue injury. However, tissue injury itself can cause ROS generation. Nevertheless, all aerobic organism, including human beings, have antioxidants defences that protect against oxidative damages, and numerous damageremoval and repair enzymes to remove or repair damaged molecules $[1,2]$.
Increased levels of oxidative stress may be implicated in the etiology of many pathological conditions. Antioxidants are thought to quench free radicals and include the endogenous enzymes such as selenium dependent glutathione peroxidase (GPX), copper-zinc dependent superoxide dismutase (SOD) and dietary antioxidants such as vitamins C, E, zinc and Phenolic compounds. Indeed, this appears to be a substantial amount of evidence suggesting that the increased intake of antioxidant rich fruit and vegetables decreases the risk for developing many chronic conditions, such as malignant and cardiovascular diseases $[3,4]$. Unfortunately, surveys indicate that the general public is far from achieving the recommended intake of the 5 to 10 servings/ day of fruit and vegetables. In recent years, there have been many food products that are available over the counter as supplements to fruit and vegetables. A large number of medicinal plants and their purified constituents have shown beneficial therapeutic potentials $[3,5]$. Various herbs and spices have been reported to exhibit antioxidant activity, including Ocimum sanctum, Piper cubeba Linn., Allium sativum Linn., Terminalia bellerica, Camellia sinensis Linn., Zingiber officinale Roscoe., and Eugenia 
aromatica. The majority of the antioxidant activity is due to the flavones, isoflavones, flavonoids, anthocyanin, coumarin lignans, catechins, and isocatechins. Antioxidant-based drug formulations are used for the prevention and treatment of complex diseases like atherosclerosis, Stroke, diabetes, Alzheimers disease and cancer $[5,6]$.

Spices and herbs are recognized as sources of natural antioxidants and thus play an important role in the chemoprevention of diseases and aging. Among those spices and herbs, clove leaf components and their active principles are well known to have potential antioxidants. There is an increasing number of literatures that recognize the antioxidant effect from clove leaf [79]. Essential oil from clove leaf mainly contains eugenol $[10,11]$. Clove oil has been also reported to have an anaesthetic effect $[12,13]$. However, there has been limited report on the total phenol components of clove leave extract and the potency of clove leave extract as an antioxidant, antihypercholesterolemic, and its function as an antiatherosclerosis in rabbit has not been explored.

\section{Material and Methods}

\section{Preparation of extracts}

Clove leaves used in this study were obtained from Zanzibar leaf type. 15 grams of clove leaves were dried on a bench. The leaves then were smashed using a blender and filtered using a filter with size of 40 mesh. The smashed clove leaves were mixed with methanol, ethanol and distilled water. Extraction was conducted using reflux method for 6 hours, then filtered using Whatman paper size of 42 , and the leaf was washed using 50 $\mathrm{mL}$ hot methanol. In order to obtain $6 \mathrm{ml}$ of clove leaf extract, the filtration results were evaporated using a vacuum rotatory evaporator at temperature $45^{\circ} \mathrm{C}$. The extraction result was left in a freezer at $-10^{\circ} \mathrm{C}$ until it was used in the experiment.

\section{Animal experiments and sampling method}

In this study, nine male rabbits from Agricultural and livestock service, weight about $\pm 3-4 \mathrm{~kg}$ were used. Rabbits were treated according to National guidelines of animals use in health research. Rabbits were divided into 3 treatment groups and each group consisted of 3 rabbits. Group 1 was a negative control group (C-), group of rabbits which were given standard feed. Group 2 was a positive control group/hypercholesterolemia $(\mathrm{C}+)$. Groups of rabbits fed a standard ration and the weight ration of $1 \%$ cholesterol for 50 days. Group $3(E D C+C)$ was a group of rabbits that were given extracts of clove leaf $(1 \mathrm{~g} / \mathrm{kg}$ bw/day) and $1 \%$ cholesterol for 50 days concurrently. Clove leaf extract was administered orally. Cholesterol was given by $1 \%$ from the average weight rations usually consumed by the rabbit. Furthermore, the rabbits consumed the ration about $100 \mathrm{~g} /$ head/day. $1 \%$ of $100 \mathrm{~g}$ or $1 \mathrm{~g} /$ head/day of the cholesterol was added to this group. Cholesterol was provided by mixing $1 \mathrm{~g}$ of cholesterol crystals into a small ration ( $30 \mathrm{~g})$. This mixture was given first to rabbits for consumption. The rest of the rations (170 $\mathrm{g}$ from a total of $200 \mathrm{~g}$ ) that did not contain cholesterol (standard feed) was given subsequently to each rabbit. In this way, the cholesterol consumed in a fixed number of rabbits per day can be ascertained. The next rabbit was given food ad libitum. After treatment, rabbits were sacrificed using atropine $1-3 \mathrm{mg} / \mathrm{kg}$ and diazepam (valium) $0.5-5 \mathrm{mg} / \mathrm{kg}$ by intramuscular injection. Liver tissue samples were taken from each rabbit. The analysis was conducted using SPSS Version 16.

\section{Liver SOD activity analysis of rabbit}

A total of $400 \mu \mathrm{L}$ solution of chilled chloroform/ethanol 37.5 / $62.5(\mathrm{v} / \mathrm{v})$ was added to $150 \mu \mathrm{L}$ liver lysate. Then divortex for three seconds and centrifuged at a speed of $4400 \mathrm{rpm}$ and temperature of $4^{\circ} \mathrm{C}$ for 10 minutes. A total of $2.9 \mathrm{ml}$ of solution A (mixture of xanthine and cytochrome c solution) plus $50 \mu \mathrm{L}$ of standard solution (control) or sample and divortex slowly. The reaction began with adding $50 \mathrm{~mL}$ solution $\mathbf{B}$ (xanthine oxidase) and divortex slowly. Observation of the absorbance changes that occur was conducted using spectrophotometer [14].

Ilmmunohistochemistry detection of $\mathrm{Cu}_{\text {, }}$ Zn-SOD.

Liver tissues were fixed for 24 hours in Bouin solution, and then processed by standard method using the paraffin. Immunohistochemical staining on liver tissue preparations of $\mathrm{Cu}, \mathrm{Zn}$-SOD was conducted in accordance with the method described by Dobashi et al. (1989) with a slight modification. After the inactivation of endogenous peroxidase, tissue sections were incubated in their monoclonal antibody anti-Cu, Zn-SOD (Sigma S2147) and followed by incubation in secondary antibody (Dako K1491). Antigenantibody reaction product was visualized with the addition of diamino benzidine (DAB). Profiles of antioxidants $\mathrm{Cu}, \mathrm{Zn}$-SOD in liver tissue were observed based on the distribution and frequency of these antioxidants and liver tissue.

Qualitative observations were made in the cytoplasm and nucleus of liver cells, and quantified in liver cell nuclei based on the intensity of brown color which was formed. The intensity of brown color indicates the content of $\mathrm{Cu}, \mathrm{Zn}-\mathrm{SOD}$, the growing prevalence of older color reaction product showed the content of $\mathrm{Cu}, \mathrm{Zn}-\mathrm{SOD}$. Quantitative observations were made to the core of the renal tubuli cells that give positive reactions in the various levels of content of $\mathrm{Cu}$, Zn-SOD (brown or tan /+++, strong positive or positive is being /++, light brown and blue mixed or weak positive /+, and blue or negative /-). Counting nuclei of cells were conducted from 5 fields of view at 400x magnification which was randomly chosen.

\section{Results and discussion}

\section{Superoxide Dismutase Activity in the liver}

Superoxide dismutase is an enzyme located in the intracellular fluid which participates in the degradation process of intracellular free radical compounds. This enzyme has an atom of oligo elements on the active side. Superoxide dismutase catalyzes dismutation $\mathrm{O}_{2} \bullet$ to $\mathrm{H}_{2} \mathrm{O}_{2}$. This enzyme inhibits the simultaneous presence of $\mathrm{O}_{2} \bullet$ and $\mathrm{H}_{2} \mathrm{O}_{2}$ derived from the formation of hydroxyl radical $(\bullet \mathrm{OH})$ (Table $\mathbf{1})$.

Analysis of the activity of superoxide dismutase (SOD) in the rabbit's liver showed that the negative control group had the highest SOD activity that is equal to $5027.90 \mathrm{U} / \mathrm{g}$ and the lowest SOD activity was observed in positive control group that is equal to $1223.33 \mathrm{U} / \mathrm{g}$. 
The provision of preventive clove leaf extract has managed to maintain SOD activity. In the extract of clove leaf, liver SOD activity decreased by $88 \%$ compared to positive controls, hereas $84.3 \%$ (Table 1).

\section{The content profiles of $\mathrm{Cu}, \mathrm{Zn}-\mathrm{SOD}$ in the liver tissue}

Immunohistochemical results revealed that $\mathrm{Cu}, \mathrm{Zn}$-SOD was found in the nucleus and cytoplasm of liver cells. The number of brown mixed with blue in the cytoplasm and nuclei of cells in the hypercholesterolemic rabbit liver indicated the declining quality of $\mathrm{Cu}, \mathrm{Zn}-\mathrm{SOD}$ content profiles compared with negative control group (C-). The magnitude of brown color was stronger in EDC+C group compared to the positive control group which revealed that there was increased content of $\mathrm{Zn}, \mathrm{Cu}-\mathrm{SOD}$ in the extract of clove leaf group $(E D C+C)$ compared to the positive control group. The content of $\mathrm{Cu}, \mathrm{Zn}-\mathrm{SOD}$ in group $\mathrm{EDC}+\mathrm{C}$ looks higher compared to most groups of positive control (Table 2 and Figure 1).

The results showed that SOD activity and content of $\mathrm{Cu}, \mathrm{Zn}-\mathrm{SOD}$ were declined, meanwhile, the MDA levels rose sharply in the rabbits' liver tissue under conditions of hypercholesterolemia. As an effect of the oxidative stress treatment in rabbits, the intensity of free radical forming was increased (Figure 1).

Free radicals were neutralized into a more stable product by intracellular antioxidant enzymes such as superoxide dismutase, catalase, and glutathione peroxidase. An increasing number of free radicals that were constantly fasting on stress conditions increased the use of intracellular antioxidant enzymes. This can decrease the activity and antioxidant content, as seen in the stress group with SOD activity and content of $\mathrm{Cu}, \mathrm{Zn}-\mathrm{SOD}$ was sharply decreased when compared to the control group.

Increased free radicals in hypercholesterolemic rabbit groups were shown in the increase of MDA levels in the liver. This caused

Table 1 The effect of clove leaf methanol extract on levels SOD and MDA in the liver rabbits.

\begin{tabular}{|c|c|c|}
\hline Groups & $\begin{array}{c}\text { SOD concentration } \\
(\mathbf{U} / \mathbf{m g})\end{array}$ & MDA ( $\boldsymbol{\mu m o l} / \mathbf{g}$ protein) \\
\hline Negative control $(n=3)$ & $357.33 \pm 43.96$ & $936.13 \pm 47.18$ \\
\hline Positive control $(=3)$ & $55.83 \pm 20.89$ & $5724.75 \pm 56.21$ \\
\hline $\begin{array}{c}\text { Clove leaf extract }+ \\
\text { cholesterol }(n=3)\end{array}$ & $566.25 \pm 48.44$ & $1720.25 \pm 3.18$ \\
\hline
\end{tabular}

Table 2 Average total of the liver cells at various level of $\mathrm{Cu}, \mathrm{Zn}$-SOD per field of view (20x).

\begin{tabular}{|c|c|c|c|c|}
\hline \multirow[t]{2}{*}{ Groups } & \multicolumn{4}{|c|}{$\begin{array}{l}\text { Average total the liver cell in level } \mathrm{Cu}, \mathrm{Zn} \text {-SOD shift } \\
\qquad(20 \mathrm{x})\end{array}$} \\
\hline & - & + & ++ & +++ \\
\hline $\begin{array}{c}\text { Negative } \\
\text { control }(n=3)\end{array}$ & 36.44 & 17.67 & 17.11 & 29.33 \\
\hline $\begin{array}{c}\text { Positive } \\
\text { control }(n=3)\end{array}$ & 127.33 & 17.00 & 2.00 & 0.00 \\
\hline $\begin{array}{l}\text { Clove leaf } \\
\text { extract + } \\
\text { cholesterol } \\
(n=3)\end{array}$ & 49.11 & 26.33 & 40.44 & 92.11 \\
\hline
\end{tabular}

Description: +++ : Strong positive, ++: being positive, +/-:weak positive the increasing use of intracellular antioxidant enzymes in the liver tissue, causing decreased activity of SOD enzyme in rabbit liver tissue in the group (Table 1).

Treatment using clove leaf extract to rabbits may help the performance of antioxidant enzymes against free radicals so that the activity of antioxidant enzymes can be maintained. The high antioxidant activity in rabbits fed a group of clove leaf extract is related to the antioxidative ability of clove leaf extract bioactive components, such as eugenol. Clove leaf extract bioactive components can work synergistically with the antioxidant enzyme in neutralizing free radicals so that the endogenous activity of endogenous antioxidant enzymes in the rabbits' liver tissue can be maintained.

\section{Analysis of MDA levels}

Analysis was performed according to MDA level. The measurement of MDA levels used spektro-flouro-meter at a wavelength of 515 $\mathrm{nm}$ excitation and $553 \mathrm{~nm}$ emission. Obtained MDA levels of samples are expressed in units of pmol per gram of protein [15].

The results show that the MDA level in the liver tissue on the positive control group is higher $(P<0.05)$ than the negative control group which it did not give $1 \%$ of cholesterol and clove leaf extract. The analysis also reveals that giving of $1 \%$ cholesterol for 50 days could give negative influence to the hipercholesterolemia group compare to negative control group. This negative influence was showed by increasing of the MDA level. A high level of MDA is a sign of the high of free radical in the body.

On condition of hypercholesterolemia, the body attempts to balance the plasma cholesterol levels by altering cholesterol into bile acids. Bile acid synthesis involves $7 \alpha$-hydroxylation, a microsomal enzyme which requires oxygen, $\mathrm{NADPH}$, and cytochrome P-450. More and more bile is synthesized, the higher the activity of cytochrome P-450 and the more oxygen is required. This increase would generate free radicals as a byproduct so that free radicals are formed excessively on the condition of hypercholesterolemia.
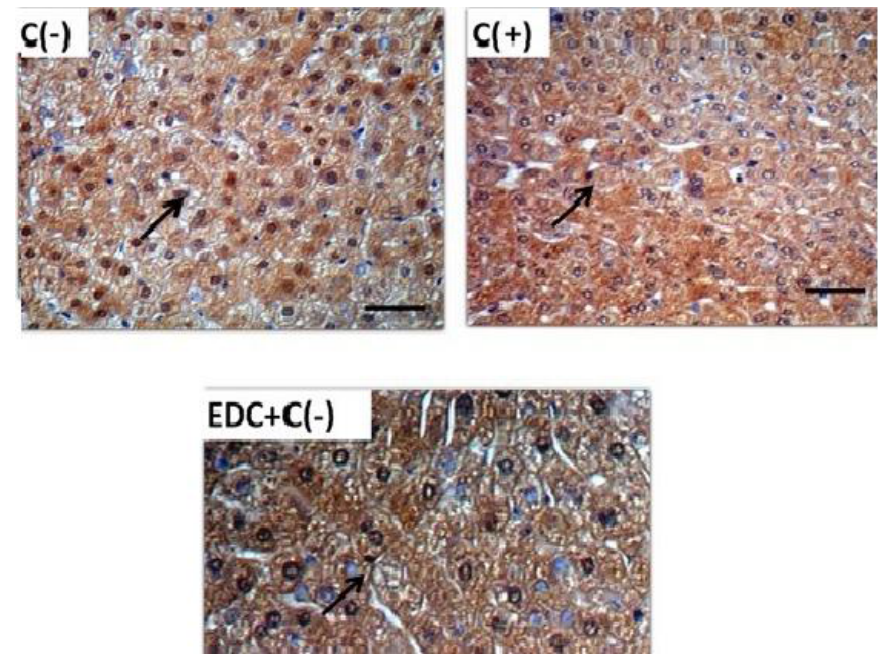

Figure 1

Photomicrograph of liver tissue treated rabbit. Immunohistochemical staining. Scale of $50 \mu \mathrm{m}$. 
Excessive lipid peroxidation levels in the blood or organs can lead to various degenerative diseases. If levels of lipid peroxidation in the liver increases, the lipid peroxidation is out of the liver into the blood vessels, and damages other organs or tissues. In humans, lipid peroxidation increases with age, but the amount should not exceed normal levels, ie $4 \mathrm{nmol} / \mathrm{ml}$ [16].

Low levels of MDA in the group of rabbits given clove leaf extract both the liver and the kidneys are intimately associated with the active component of the clove leaf extract. The active component of clove leaf extract is a powerful component of phenol was detected in the phytochemical test. Phenolic compounds have the ability as a primary antioxidant activity so that the ability of the lipid peroxidation process and other processes that can produce malondialdehid can be reduced

Phenol type antioxidant activity is related to the balance of oxidation- reduction (redox), namely electron donating substituent attached to the aromatic rings is increased the speed of reaction inhibition of oxidation by antioxidants. It is also believed that antioxidant prevents oxidation and free radical chain donated the hydrogen atoms of phenolic hydroxyl groups and form a stable product [17]. One of phenol derivatives on cloves is eugenol. It has been reported that the compound eugenol contained in the cloves methanol extract can inhibit lipid peroxidation in the initiation and propagation stages or both and reaction inhibition of eugenol together with $\alpha$-tocopherol in vitro $[18,19]$.

\section{Conclusions}

Provision of clove leaf extract can overcome superoxide dismutase and malondialdehide profiles in rabbits' liver tissue under condition of hypercholesterolemia. The extract of clove leaf preventively maintained SOD activity and content of $\mathrm{Cu}, \mathrm{Zn}$ SOD, and MDA levels. The extract of clove leaf that was given to the rabbits simultaneously for 50 days increased both SOD activity (8.992 times) and $\mathrm{Cu}, \mathrm{Zn}-\mathrm{SOD}$ content, and decreased MDA level to $232.785 \%$. 


\section{References}

Yildirim A, Munir O, Vahit B (2001) The antioxidant activity of the leaves of cydonia vulgaris. Turk J Med Sci 31: 23-27.

2 Devasagayam T PA, Tilak JC, Boloor KK, Sane KS, Ghaskadbi SS, et al. (2004) Free radicals and antioxidants in human health: current status and future prospects. The Journal of the Association of Physicians of India 52: 794-804.

Aqil F, Ahmad I, Mehmood Z (2006) Antioxidant and free radical scavenging properties of twelve traditionally used indian medicinal plants. Turk J Biol 30: 177-183.

4 Halliwell B (1994) Free radicals and antioxidants: a personal view. Nutrition reviews, 52: 253-265.

Howard LR, Pandjaitan N, Morelock T, Gil MI (2002) Antioxidant capacity and phenolic content of spinach as affected by genetics and growing season. Journal of Agricultural and Food Chemistry, 50 5891-5896.

Khalaf NA, Ashok KS, Atif A, Zaha E, Husni F (2007) Antioxidant activity of some common plants. Turk J Biol 31: 1-5.

Bhuiyan M NI, Begum J, Nandi NM, Akter F (2010) Constituents of the essential oil from leaves and buds of clove (syzigium caryophyllatum (I.) alston). African Journal of Plant Science 4: 451-454.

Milind P, Deepa K (2011) Clove : A champion spice. International Journal of Research an Ayurveda and Pharmacy 2: 47-54.

Abozid MM, El-Sayed SM (2013) Antioxidant and protective effect of clove extracts and clove essential oil on hydrogen peroxide treated rats. International Journa of ChemTech Research 5: 1477-1485.

10 Alma MH, Ertaş M, Nitz S, Kollmannsberger H (2007) Chemical composition and content of essential oil from the bud of cultivated turkish clove (syzygium aromaticum I.) Bio Resources 2: 265-269.
Nassar MI, Gaara AH, El-Ghorab AH, Farrag AH, Shen $\mathrm{H}$, et al. (2007) Chemical constituents of clove (syzygium aromaticum, fam. myrtaceae) and their antioxidant activity. Rev. Latinoamer. Quim 35: 45-57.

Grush J, Noakes D LG, Moccia RD (2004) The efficacy of clove oil as an anesthetic for the zebrafish, danio rerio (hamilton). Zebrafish 1: 46-53.

Velisek J, Svobodova Z, Piackova V, Groch L, Nepejchalova L (2005) Effects of clove oil anaesthesia on common carp (cyprinus carpio I.). Vet Med 50: 269-275.

14. Paoletti F, Aldinucci D, Mocali A, Caparrini A (1986) A sensitive spectrophotometric methods for the determination of superoxide dismutase activity in tissue extracts. Anal Biochem 154: 536-541.

15 Esterbauer H, Cheeseman KK (1990) Determination of aldehydic lipid peroxidation products: malonaldehyde and 4-hydroxynonenal. Methods in enzymology 186: 407-421.

16 Yagi K (1994) Lipid Peroxides in Hepatic, Gastrointestinal, and Pancreatic Disease. Free Radicals in Diagnostic Medicine. New York : Plenum Press.

7 Chidambara KN, Singh RP, Jayaprakasha GK (2002) Antioxidant activities of grape (Vitis vinivera) pomace extracts. J Agric Food Chem 50: 5909-5914.

8 Ogata M, Hoshin M, Rano S, Endo T (2000) Antioxidant activity of eugenol and related monomeric and dimeric compounds. Chem Pharm Bull 48: 147-149.

Jirovetz L, Buchbauer J, Stoilova I, Stoyanova A, Krastanov A, et al. (2006) Chemical composition and antioxidant properties of clove leaf essential Oil. Journal of Agricultural and Food Chemistry 17: 6303-6307. 